\title{
Sharia Banking Sustainability: Instrument Development of Islamic Banking Sustainability
}

\author{
Basrowi $^{1} \&$ Tulus Suryanto ${ }^{2}$ \\ \{basrowi2018@gmail.com ${ }^{1}$, tulus@ radenintan.ac.id $\left.{ }^{2}\right\}$
}

Sekolah Tinggi Ekonomi dan Bisnis Islam Lampung, Indonesia ${ }^{1}$, Faculty of Economics and Islamic Business, Universitas Islam Negeri (UIN) Raden Intan Lampung, Indonesia ${ }^{2}$

\begin{abstract}
Until now, there is no instrument that can be used to measure the sustainability of Islamic banks. In fact, in the midst of very tight competition with conventional banks and financial technology which is developing at a fast pace, a measuring tool is needed to determine how far Islamic banks are able to compete towards sustainability. The purpose of this research is to develop an instrument that can measure the level of sustainability of Islamic banks in terms of business, investment, Human resource management (HRM), and reporting. The method used is the development of an instrument that includes steps for reading theory, developing a grid, content analysis, empirical testing, analysis and drawing conclusions. The instrument was tested on as many as 250 customers of BRI sharia banks, BNI Sharia, and Bank Sharia Mandiri. Data analysis using factor analysis method. The results of the calibration analysis show that the instrument is feasible to be tested on a wider scope, in order to obtain greater consistency.
\end{abstract}

Keywords: Sustainability, Islamic bank, instrument, measurement.

\section{Introduction}

The Islamic banking industry in Indonesia is undergoing fundamental changes due to a number of driving factors such as market liberalization, stakeholder expectations, and environmental risks. This has resulted in the development of the Islamic banking market experiencing an unprecedented pace. Going forward, the Islamic banking industry must continue to look for ways to increase sustainability and profitability while balancing the demands of regulatory changes. This shows the importance of sustainability in ensuring the long-term survival of the bank [1][2].

Banks in realizing sustainable development should not only move on rhetoric, but must really strive to realize sustainable development as a decision-making strategy [3]. Banking in financial reports for the public must include economic, environmental and social information. The report is intended to help audiences make informed decisions. This is motivated by the demands of stakeholders and shareholders including regulators, society, customers, and employees. Disclosure of corporate sustainability is a means of communicating with stakeholders about the company's economic, environmental and social performance. A sustainability report shows the company's responsiveness to social problems and can also serve as a signal that the company wants to position itself in the perspective of a wider community [1].

The banking industry has started to respond to this pressure by adopting the pillars of sustainability and disclosing social and environmental reports. They have a responsibility in 
the sustainable development process [4]. Banks play a key role in society and an important one for economic development [5]. Thus, they bear a big responsibility for sustainable development. Some experts argue that the financial or banking sector should play an important role in the transformation of a more sustainable economic system in order to reduce the negative effects from the external side [6].

Currently, the sustainability of the banking industry has a very important meaning. The approach used also covers broader and deeper things. Moreover, currently the sustainability of the bank is gaining new momentum, driven by encouragement from governments around the world, and the growing body of evidence that supports banking finance in a sustainable manner [7].

Data from the Global Sustainable Investment Alliance (WF Banking, 2017) states that sustainable, responsible and impactful investment assets amounted to \$22.89 trillion worldwide, in 2016. This is an increase of 25 percent compared to 2014, which previously increased 61 percent from 2012 [7].

However, even though the amount of growth in the banking industry is striking, there is a long way to go. For example, according to research results from the United Nations Environment Program, green bonds accumulated are still less than one percent of total bond issues. Moreover, only 10 percent of bank loans are considered 'green' according to existing national standards [7].

Advanced ways of measuring banking sustainability throughout the financial system will be critical to overall progress on the sustainability agenda. Ultimately, it is highly relevant both from a policy-based perspective in understanding how the sustainable finance agenda is evolving

\section{Literature Review}

Adams \& Narayanan (2007) considers that the issue of sustainability is one of the most important issues for industry around the world. Sustainability consists of two major concepts, namely (1) the concept of needs, in particular the essential needs of the world's poor, which must be given top priority, and (2) the idea of limits imposed by the state of technology and social organization of the ability of the environment to meet present and future needs [8].

Company sustainability shows the inclusion of social and environmental concerns in business operations and interacting with stakeholders (Roca \& Searcy, 2012). From an organizational perspective, sustainability is defined as an effort to meet the needs of a company's direct and indirect stakeholders without sacrificing the ability to meet the needs of future stakeholders [9].

Sustainable business efforts are carried out to minimize various obstacles and challenges for the company. Sustainable development is a business model that manages triple bottom online where the company manages five main fulcrums (5Ps), namely finance (profit), planet, prosperity and peace, partnerships and social environmental impacts and social welfare (people) [10] are equally different from conventional ways where companies only think in terms of finances without thinking about the effects on the environment and social life [11]. Several previous studies have linked triple bottom online with corporate sustainability [12] where the method is not only safe for the surrounding environment, but also has good quality to succeed in a competitive international market.

Sustainability human resources management (HRM) is a design option for working relationships and as a contribution to the development of a sustainable company. The company believes that sustainability is more than just economical and environmentally 
friendly. But also about other aspects such as employee development, work ability, employee health and welfare, employee participation, and fairness. There are four dimensions of sustainable HRM, namely justice and welfare, transparent HR practices, profitability, and employee welfare. Four broader areas of responsibility were also identified, namely legal and ethical, managerial, social and economic [13].

Financial sustainability studies the contract design problems faced by organizations or companies in the scope of financial lending by taking into account the outreach, sustainability, and impact of loans on lending targets. Sustainable finance aims to encourage financial service institutions to implement more environmentally friendly financial practices by 'greening' their customer base and prioritizing financial transactions for environmentally friendly business projects.

Altuntas and Turker (2012) analyze how sustainable supply chains are strategically conceptualized and practiced [14]. Value-based bankers are increasingly aware of the importance of the real economy, social cohesion and the natural human ecosystem. These three things are at the core of the sustainable banking business model. The focus on investment sustainability moves to regulation in the banking sector. Customers can also find out the sustainability of their investment, through internet technology. Banks must be able to provide infestation grow application services, as robots that are able to monitor financial benefits and wider social effects [7].

The dimension of sustainability includes the nature of bank services which are highly dependent on the production and processing of information and social networks. Corporate social responsibility, increased interconnectivity, increased homogeneity, decreased diversity, human culture, institutions, practices and technology [15].

Sustainability report is a form of corporate responsibility to the public, so that the public will also provide an assessment of the company's performance. Continuous reporting as a type of non-financial report is a practice of measuring, disclosing and being accountable to stakeholders for organizational performance [16]. Sustainable reporting shows a movement towards increasing transparency and business in relation to accountability to a higher level [17].

Wass et.al. (2014) suggest the use of three indicators when measuring banking sustainability, namely: interpretation, information structuring, and influence. Other experts see that the sustainability of banking can be seen from: 1) equality (justice), 2) dynamics (changes due to the changing environment and society, to trigger uncertainty and the need for prudence, 3 ) integration (combining finance and the environment), 4) normativity (sustainable development as a social construction as a form of normative choice) [3].

\section{Methods}

The method used in the development of Islamic banking sustainability instruments is to use standardized instruments by calibrating the instruments that have been developed, based on empirical trial data in order to obtain measuring instruments that have high validity and have a high level of reliability. The results of the development of this measuring instrument can be re-measured by other researchers in other places at different times. This measuring tool can be used by all researchers, because it has a high level of validity and reliability.

The ppopulation in this study are customers of the 3 largest Islamic banks in Indonesia which are registered at BI. In conducting this research, data collection was carried out through the distribution of survey instruments using goggle form to obtain the latest information 
availability. This research is based on construct, content, and empirical analysis to measure the quality of sustainability disclosure.

Construct and content analysis refers to existing theories, as well as dimensions and indicators that have been proposed by experts. Empirical analysis was performed using factor analysis.

For this purpose, the information provided by the customer when filling out the instrument is the customer's perception of the sustainability of the Islamic bank in the future, based on the quality of services provided. Through a survey it was possible for researchers to take 3 commercial Islamic banks in operation. The three selected banks, namely BRI Sharia, BNI Sharia, and Bank Sharia Mandiri, all of which inform their stakeholders about sustainable performance. They finance environmental protection and operate on a social responsibility basis. Finally, we obtained a dataset consisting of balanced instrument calibration survey data from customers of 3 commercial Islamic banks.

Indicators in the preparation of bank sustainability instruments are divided into three groups of indicators, namely disclosure of financial sustainability, disclosure of consumption and energy savings, and disclosure of product responsibility.

Table 1. Sharia Banking Institution Sustainability Indicators

\begin{tabular}{|c|c|c|c|}
\hline Dimension & Indicators & Sub-indicators & $\begin{array}{c}\text { Item } \\
\text { Number }\end{array}$ \\
\hline \multirow[t]{10}{*}{$\begin{array}{l}\text { Sharia business } \\
\text { sustainability }\end{array}$} & \multirow[t]{2}{*}{$\begin{array}{l}\text { Radical resource } \\
\text { productivity }\end{array}$} & $\begin{array}{l}\text { Reducing or abandoning the use of natural } \\
\text { resources in the production process; }\end{array}$ & 1 \\
\hline & & $\begin{array}{l}\text { Eliminates dependence on energy or non- } \\
\text { renewable resources }\end{array}$ & 2 \\
\hline & \multirow[t]{2}{*}{$\begin{array}{l}\text { Investment in } \\
\text { Natural capital }\end{array}$} & $\begin{array}{l}\text { Running energy or resources while } \\
\text { maintaining the environment in sharia }\end{array}$ & 3 \\
\hline & & Using resources in sharia & 4 \\
\hline & \multirow{2}{*}{$\begin{array}{l}\text { Ecological } \\
\text { redesign }\end{array}$} & Using a closed-loop production system & 5 \\
\hline & & Doing recycling & 6 \\
\hline & \multirow{2}{*}{$\begin{array}{l}\text { Service and flow } \\
\text { economy }\end{array}$} & Sharia product leasing & 7 \\
\hline & & Reducing Waste in sharia & 8 \\
\hline & \multirow{2}{*}{$\begin{array}{l}\text { Responsible } \\
\text { consumption }\end{array}$} & Sharia product promotion & 9 \\
\hline & & Sharia Consumer Education & 10 \\
\hline \multirow{7}{*}{$\begin{array}{l}\text { Sharia HRM } \\
\text { Sustainability }\end{array}$} & \multirow[t]{2}{*}{ Justice } & Sustainable justice according to sharia & 11 \\
\hline & & $\begin{array}{l}\text { Opportunities for employees to participate } \\
\text { in a sustainable manner according to sharia }\end{array}$ & 12 \\
\hline & \multirow[t]{2}{*}{$\begin{array}{l}\text { Transparent HR } \\
\text { practices }\end{array}$} & $\begin{array}{l}\text { Increase work capacity in a transparent } \\
\text { manner according to sharia }\end{array}$ & 13 \\
\hline & & transparent employee development & 14 \\
\hline & \multirow[t]{2}{*}{ Profitability } & $\begin{array}{l}\text { The role of HR in generating profits } \\
\text { according to sharia }\end{array}$ & 15 \\
\hline & & $\begin{array}{l}\text { Sustainable HR competencies according to } \\
\text { sharia }\end{array}$ & 16 \\
\hline & Employee welfare & $\begin{array}{l}\text { sustainable employee welfare according to } \\
\text { sharia }\end{array}$ & 17 \\
\hline
\end{tabular}




\begin{tabular}{|c|c|c|c|}
\hline Dimension & Indicators & Sub-indicators & $\begin{array}{c}\text { Item } \\
\text { Number }\end{array}$ \\
\hline & & $\begin{array}{l}\text { Sustainable employee health according to } \\
\text { sharia }\end{array}$ & 18 \\
\hline \multirow{4}{*}{$\begin{array}{l}\text { Sharia Financial } \\
\text { Sustainability }\end{array}$} & \multirow{3}{*}{$\begin{array}{l}\text { Roadmap of } \\
\text { financial } \\
\text { sustainability }\end{array}$} & Current position & 19 \\
\hline & & The position to be aimed at in sharia & 20 \\
\hline & & Strategy towards sharia economy & 21 \\
\hline & $\begin{array}{l}\text { Operational } \\
\text { Sustainability }\end{array}$ & Sharia economic general policies & 22 \\
\hline \multirow[t]{10}{*}{$\begin{array}{l}\text { Sharia } \\
\text { investment } \\
\text { sustainability }\end{array}$} & \multirow[t]{3}{*}{$\begin{array}{l}\text { Financial } \\
\text { sustainability }\end{array}$} & $\begin{array}{l}\text { Funds for social: the poor, the disabled, the } \\
\text { elderly, the children in the children's house, } \\
\text { charity activities, own foundation according } \\
\text { to sharia }\end{array}$ & 23 \\
\hline & & The amount of funds allocated in sharia & 24 \\
\hline & & Sharia Donation Value & 25 \\
\hline & \multirow[t]{4}{*}{$\begin{array}{l}\text { Consumption and } \\
\text { energy savings }\end{array}$} & $\begin{array}{l}\text { Sharia environmental credit risk assessment } \\
\text { procedures }\end{array}$ & 26 \\
\hline & & $\begin{array}{l}\text { Initiatives to provide sustainability products } \\
\text { and services according to sharia }\end{array}$ & 27 \\
\hline & & $\begin{array}{l}\text { support for businesses that adopt } \\
\text { environmentally friendly practices } \\
\text { according to sharia }\end{array}$ & 28 \\
\hline & & $\begin{array}{l}\text { Energy Consumption and Disclosure of } \\
\text { Savings Environmental strategies for } \\
\text { Islamic banks }\end{array}$ & 29 \\
\hline & \multirow{3}{*}{$\begin{array}{l}\text { Product } \\
\text { responsibility }\end{array}$} & Raw materials for halal products & 30 \\
\hline & & $\begin{array}{l}\text { The production process becomes finished } \\
\text { goods pages }\end{array}$ & 31 \\
\hline & & $\begin{array}{l}\text { Product recycling in maintaining } \\
\text { environmental sustainability according to } \\
\text { sharia }\end{array}$ & 32 \\
\hline \multirow{11}{*}{$\begin{array}{l}\text { Sharia Reporting } \\
\text { Sustainability }\end{array}$} & \multirow{4}{*}{$\begin{array}{l}\text { Economic } \\
\text { Indicators }\end{array}$} & Direct economic value according to sharia & 33 \\
\hline & & $\begin{array}{l}\text { Economic value is distributed according to } \\
\text { sharia }\end{array}$ & 34 \\
\hline & & Islamic market development & 35 \\
\hline & & Muslim community investment & 36 \\
\hline & \multirow{6}{*}{$\begin{array}{l}\text { Environment } \\
\text { Indicators }\end{array}$} & Halal material & 37 \\
\hline & & Energy kosher & 38 \\
\hline & & Water & 39 \\
\hline & & Emission & 40 \\
\hline & & Recycle on page basis & 41 \\
\hline & & Indirect Impact & 42 \\
\hline & Social indicators & Muslim employment & 43 \\
\hline
\end{tabular}




\begin{tabular}{|c|c|c|c|}
\hline Dimension & Indicators & Sub-indicators & $\begin{array}{c}\text { Item } \\
\text { Number }\end{array}$ \\
\hline & & Islamic economics education and training & 44 \\
\hline
\end{tabular}

Source: Theory Reading Results

In analysing the data that has been collected, factor analysis is used.

\section{Results}

The determinant of correlation matrix 2.685E-14, the determinant number of the matrix is close to zero, meaning that there is sufficient correlation between variables. The determinant value of the correlation matrix whose elements resemble the identity matrix will have a determinant value of one.

Table 2. KMO and Bartlett's Test

\begin{tabular}{|c|c|c|}
\hline \multicolumn{2}{|c|}{ Kaiser-Meyer-Olkin Measure of Sampling Adequacy. } & .731 \\
\hline \multirow{3}{*}{ Bartlett's Test of Sphericity } & Approx. Chi-Square & 7296.561 \\
\hline & Degree of freedom. & 946 \\
\hline & Sig. & .000 \\
\hline $\begin{array}{l}\text { Correlation Matrix } \\
\text { a. } \text { Determinant }=\mathbf{2 . 6 8 5 E - 0 1 4}\end{array}$ & & \\
\hline
\end{tabular}

Source: 2020 data analysis results

The KMO value is an identity of the comparison of the distance between the correlation coefficient and the partial correlation coefficient. If the sum of the squares of the partial correlation coefficient between all pairs of variables is small compared to the sum of squares of the correlation coefficient, the value of KMO will be close to one.

A small KMO value indicates that the factor analysis is not appropriate, based on the output above the KMO value $=0.731$. Bartlett's test shows the number 422.301 with a significance of $0.000<\alpha(0.05)$, this shows that the correlation matrix being tested is not an identity matrix.

In the anti-image matrices table above, especially in the anti-image correlation section, you can see a number of numbers that form a diagonal (marked 'a' and have been given a circle) which indicates the magnitude of the MSA value of a variable. The MSA value is the value of the comparison of the distance between the correlation coefficient and the partial correlation coefficient. To be able to do factor analysis, the MSA value must be greater than 0.5. Based on the anti-image matrices output above all MSA values are $>0.5$ so we can continue the discussion. If the MSA value $<0.5$ means enough discussion here.

In the Communalities table, the Initial value is the variable variant before extracting. All initials have a value of 1 , this means that prior to extraction, the variable $100 \%$ forms this factor, because the factor before extraction is the same as the variable. Thus there are still 44 items.

Table 3. Total Variance Explained 


\begin{tabular}{|c|c|c|c|c|c|c|c|c|c|}
\hline \multirow[t]{2}{*}{$\begin{array}{l}\text { Componen } \\
\mathrm{t}\end{array}$} & \multicolumn{3}{|c|}{ Initial Eigenvalues } & \multicolumn{3}{|c|}{$\begin{array}{c}\text { Extraction Sums of Squared } \\
\text { Loadings }\end{array}$} & \multicolumn{3}{|c|}{$\begin{array}{c}\text { Rotation Sums of Squared } \\
\text { Loadings }\end{array}$} \\
\hline & Total & $\begin{array}{c}\% \text { of } \\
\text { Variance }\end{array}$ & $\begin{array}{l}\text { Cumulat } \\
\text { ive } \%\end{array}$ & Total & $\begin{array}{c}\% \text { of } \\
\text { Variance }\end{array}$ & $\begin{array}{l}\text { Cumulativ } \\
\text { e } \%\end{array}$ & Total & $\begin{array}{c}\% \text { of } \\
\text { Variance }\end{array}$ & Cumulative $\%$ \\
\hline 1 & 6.110 & 13.887 & 13.887 & 6.110 & 13.887 & 13.887 & 4.294 & 9.759 & 9.759 \\
\hline 2 & 4.799 & 10.907 & 24.794 & 4.799 & 10.907 & 24.794 & 3.346 & 7.604 & 17.364 \\
\hline 3 & 4.099 & 9.315 & 34.109 & 4.099 & 9.315 & 34.109 & 3.078 & 6.994 & 24.358 \\
\hline 4 & 3.365 & 7.648 & 41.756 & 3.365 & 7.648 & 41.756 & 2.893 & 6.574 & 30.932 \\
\hline 5 & 2.811 & 6.388 & 48.145 & 2.811 & 6.388 & 48.145 & 2.844 & 6.463 & 37.395 \\
\hline 6 & 2.255 & 5.124 & 53.268 & 2.255 & 5.124 & 53.268 & 2.768 & 6.292 & 43.687 \\
\hline 7 & 2.049 & 4.657 & 57.926 & 2.049 & 4.657 & 57.926 & 2.601 & 5.912 & 49.599 \\
\hline 8 & 1.850 & 4.205 & 62.131 & 1.850 & 4.205 & 62.131 & 2.532 & 5.756 & 55.354 \\
\hline 9 & 1.730 & 3.932 & 66.063 & 1.730 & 3.932 & 66.063 & 2.248 & 5.110 & 60.464 \\
\hline 10 & 1.469 & 3.338 & 69.402 & 1.469 & 3.338 & 69.402 & 2.074 & 4.715 & 65.178 \\
\hline 11 & 1.243 & 2.826 & 72.228 & 1.243 & 2.826 & 72.228 & 1.978 & 4.497 & 69.675 \\
\hline 12 & 1.134 & 2.578 & 74.806 & 1.134 & 2.578 & 74.806 & 1.951 & 4.435 & 74.110 \\
\hline 13 & 1.059 & 2.406 & 77.212 & 1.059 & 2.406 & 77.212 & 1.365 & 3.102 & 77.212 \\
\hline 14 & .796 & 1.808 & 79.020 & & & & & & \\
\hline
\end{tabular}

Source: 2020 data analysis results

Based on the Total Variance Explained output, information can be obtained that the number of factors formed is 13 factors, namely the first factor has an eigenvalue $=9,759$, the second factor has an eigenvalue $=7,604$, and the third factor has an eigenvalue $=6,994$. The total sum of all eigenvalues $=77,212$ or equal to the sum of the total variants.

The percentage of variance by factor 1 is $13,887(6.110 / 44) \times 100 \%=13,887 \%$. The percentage of variance by factor 2 is $24,794(4,799 / 44) \times 100 \%=24,794 \%$. The percentage of variance by factor 3 is $34,109(4,099 / 44) \times 100 \%=34,109 \%$ and so on.

Based on the output, it is obtained thirteen factors, each of which has a percentage of variance of 13,$887 ; 10,907 ; 9,315$ and so on, so that the total percentage of variance of the three factors is $77,212 \%$. Thus $77,212 \%$ of all variables can be explained by the thirteen formed factors. This instrument is able to raise $77.22 \%$ of its hidden dimensions. The remaining $32.78 \%$ cannot be manifested through this instrument.

The Component Matrix diagram shows the distribution of the variables that have been extracted into factors that are formed based on their loading factors.

Variables are included in the factors that have the largest loading factor. The loading factor shows the closeness of a variable to the formed factors. The greater the loading factor value, the more significantly the variable can be included in one of the factors that are formed, and vice versa.

In some cases, it can be found that a variable has the same relative closeness with several factors, so it needs to be rotated. The Rotated Component Matrix table shows the distribution of the variables that have been extracted into the factors that have been formed based on the loading factor after the rotation process is carried out. The loading factor value may change after rotation.

Variables that have a loading factor value $<0.400$ are considered to have a weak contribution to the formed factors, so they must be reduced from the factors that are formed.

Based on the output of the Component Matrix above, it can be seen that: instrument items that enter factor 1, namely items number 6, 7, 5, and 8. Instrument items that enter factor 2 , namely item items number 19, 18, 20, and 17. Instrument items that fall into factor 3 , namely items number $11,10,12$, and 9 . Instrument items included in factor 4 , namely items number $23,22,24$, and 21 . Instrument items that are included in factor 5, namely items number $14,15,13$, and 16 . Instrument items included in factor 6 , namely items number 42 , 43, 44, and 38. Instrument items included in factor 7, namely items number 27, 26, 28, and 25. 
Instrument items included in factor 8 , namely items number 1, 2, and 3. Instrument items included in factor 9, namely items no. 40, 39, and 41. Instrument items included in factor 10, namely items number 32, 31, and 33. Instrument items that were included in the 11th factor were items number 36, 35, and 37. Instrument items that are included in factor 12, namely items number 30 and 29. Instrument items that are included in factor 13, namely item number 34.

\begin{tabular}{|c|c|c|c|}
\hline Factor & Eigenvalue & $\begin{array}{c}\text { Item } \\
\text { number }\end{array}$ & $\begin{array}{c}\text { Loading } \\
\text { factor }\end{array}$ \\
\hline \multirow{5}{*}{1} & \multirow{5}{*}{9,759} & Item_6 & 0,906 \\
\hline & & Item_7 & 0,885 \\
\hline & & Item_5 & 0,874 \\
\hline & & Item_8 & 0,784 \\
\hline & & Item_4 & 0,769 \\
\hline \multirow{4}{*}{2} & \multirow{4}{*}{7.604} & Item_19 & 0,898 \\
\hline & & Item_18 & 0,858 \\
\hline & & Item_20 & 0,760 \\
\hline & & Item_17 & 0,751 \\
\hline \multirow{4}{*}{3} & \multirow{4}{*}{6,994} & Item_11 & 0,890 \\
\hline & & Item_10 & 0,841 \\
\hline & & Item_12 & 0,765 \\
\hline & & Item_9 & 0,620 \\
\hline \multirow{4}{*}{4} & \multirow{4}{*}{6,574} & Item_23 & 0,820 \\
\hline & & Item_22 & 0,786 \\
\hline & & Item_24 & 0,772 \\
\hline & & Item_21 & 0,740 \\
\hline \multirow{4}{*}{5} & \multirow{4}{*}{6.463} & Item_14 & 0,831 \\
\hline & & Item_15 & 0,802 \\
\hline & & Item_13 & 0,735 \\
\hline & & Item_16 & 0,610 \\
\hline \multirow{4}{*}{6} & \multirow{4}{*}{6.292} & Item_42 & 0,858 \\
\hline & & Item_43 & 0,857 \\
\hline & & Item 44 & 0,820 \\
\hline & & Item_38 & 0,462 \\
\hline \multirow{4}{*}{7} & \multirow{4}{*}{5,912} & Item_27 & 0,870 \\
\hline & & Item_26 & 0,840 \\
\hline & & Item_28 & 0,722 \\
\hline & & Item_25 & 0,558 \\
\hline \multirow{3}{*}{8} & \multirow{3}{*}{5,756} & Item_1 & 0,884 \\
\hline & & Item_2 & 0,834 \\
\hline & & Item_3 & 0,728 \\
\hline \multirow{3}{*}{9} & \multirow{3}{*}{5.110} & Item_40 & 0,808 \\
\hline & & Item_39 & 0,804 \\
\hline & & Item_41 & 0,490 \\
\hline \multirow{3}{*}{10} & \multirow{3}{*}{4,715} & Item_32 & 0,808 \\
\hline & & Item_32 & 0,804 \\
\hline & & Item_33 & 0,490 \\
\hline 11 & 4,497 & Item_36 & 0,854 \\
\hline
\end{tabular}




\begin{tabular}{c|c|c|c}
\hline Factor & Eigenvalue & $\begin{array}{c}\text { Item } \\
\text { number }\end{array}$ & $\begin{array}{c}\text { Loading } \\
\text { factor }\end{array}$ \\
\hline & & Item_35 & 0,809 \\
& & Item_37 & 0,470 \\
\hline 12 & 4,435 & Item_30 & 0,847 \\
& & Item_29 & 0,821 \\
\hline 13 & 3.102 & Item_34 & 0,807 \\
\hline
\end{tabular}

Source: 2020 data analysis results

\section{Conclusions}

Based on the results of the analysis, there are thirteen factors that can be used to measure the sustainability of Islamic banking. The most dominant factor is the factor that has the greatest eigenvalue value.

While the item items that are able to predict or describe the problem, there are 44 item items from 44 item items made by the researcher. Thus, there are no items that are reduced (excluded) because none of them have a factor loading value smaller than 0.4 . The results of the calibration analysis show that the instrument is feasible to be tested on a wider scope, in order to obtain greater consistency

The basic thing that needs to be understood is that the factors which are stated as dominant factors do not mean that these factors have the greatest influence on the sustainability of Islamic banking. To analyse the dimensions that have the most influence on banking sustainability, it is necessary to carry out further analysis which is a causal analysis such as path analysis or structural equation models.

\section{Acknowledgements}

Thanks to the Chairperson of the College of Economics and Islamic Business (STEBI) Lampung, Indonesia who has facilitated this research until it is complete and worthy of publication.

\section{References}

[1] N. A. Harun, A. A. Rashid, and B. Alrazi, Handbook on the Economic, Finance and Management Outlooks. Malaysia: PAK Publishing Group, 2013.

[2] P. Utami, "Digital Banking Reflection and Zakat Accoutability Sharia Banking in Indonesia," East. J. Econ. Financ., vol. 4, no. 1, pp. 31-40, 2019.

[3] T. Waas, J. Hugé, A. Verbruggen, and T. Wright, "Sustainable development: A bird's eye view," Sustainability, vol. 3, no. 10, pp. 1637-1661, 2011.

[4] F. Özçelik and B. A. Öztürk, "Türkiye’de Bankaların Sürdürülebilirlik Performanslarının Gri İlişkisel Analiz Yöntemiyle Değerlendirilmesi," Muhasebe ve Finans. Derg., no. 63, pp. 189-210, 2014.

[5] B. Scholtens and S. van't Klooster, "Sustainability and bank risk," Palgrave Commun., vol. 5, no. 1, pp. 1-8, 2019.

[6] E. Kemp-Benedict, "Investing in a Green Transition," Ecol. Econ., vol. 153, no. September 2017, pp. 218-236, 2018.

[7] World Financial Banking, "Sustainable banks: Growing Strong," worldfinance.com, 
2017.

[8] C. A. Adams and N. Kuasirikun, "A comparative analysis of corporate reporting on ethical issues by UK and German chemical and pharmaceutical companies," Eur. Account. Rev., vol. 9, no. 1, pp. 53-79, 2000.

[9] F. K. Turan, N. M. Scala, M. Besterfield-Sacre, and K. L. Needy, "An Analytic Network Process (ANP) Approach to the Project Portfolio Management for Organizational Sustainability," IIE Annu. Conf. Proc., pp. 308-313, 2009.

[10] J. Elkington, Cannibals with forks: the triple bottom line of twenty-first century business. Capstone, 1997.

[11] Y. Wibisono, Membedah Konsep \& Aplikasi CSR (Corporate Social Responsibilty). Jakarta: Gramedia, 2007.

[12] D. K. Nayyira, "Apa yang dimaksud dengan Bisnis Berkelanjutan atau Sustainable Business. dictio.id. URL: https://www.dictio.id/t/apa-yang-dimaksud-dengan-bisnisberkelanjutan-atau- sustainable-business/15047," www.dictio.id, 2018. [Online]. Available: https://www.dictio.id/t/apa-yang-dimaksud-dengan-bisnis-berkelanjutanatau- sustainable-business/15047.

[13] C. Voegtlin and M. Greenwood, "Corporate social responsibility and human resource management: A systematic review and conceptual analysis," Hum. Resour. Manag. Rev., vol. 26, no. 3, pp. 181-197, 2016.

[14] C. Altuntaş and D. Türker, "Sürdürülebilir tedarik zincirleri: sürdürülebilirlik raporlarının içerik analizi,” Dokuz Eylül Üniversitesi Sos. Bilim. Enstitüsü Derg., vol. 14, no. 3, pp. 39-64, 2012.

[15] T. Homer-Dixon et al., "Synchronous failure: The emerging causal architecture of global crisis," Ecol. Soc., vol. 20, no. 3, 2015.

[16] H. Fauzi, G. Svensson, and A. A. Rahman, "“Triple bottom line' as 'sustainable corporate performance': A proposition for the future," Sustainability, vol. 2, no. 5, pp. 1345-1360, 2010.

[17] A. Jackson, K. Boswell, and D. Davis, "Sustainability and Triple Bottom Line Reporting - What is it all about?," Int. J. Business, Humanit. Technol., vol. 1, no. 3, pp. 55-59, 2011. 